\title{
MINERAL RESOURCES OF THE NORTH SISTERS ROCKS WILDERNESS STUDY AREA, CURRY COUNTY, OREGON
}

B y

\author{
Scott A. Minor ${ }^{1}$ and Harley D. King ${ }^{2}$ \\ U.S. Geological Survey \\ and \\ Harry W. Campbell ${ }^{3}$ \\ U.S. Bureau of Mines
}

U.S. Geological Survey

Open-File Report 88-12

Prepared by the U.S. Geological Survey and the U.S. Bureau of Mines
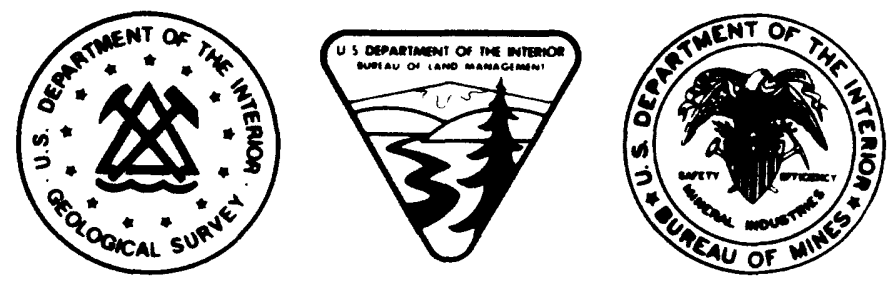

for the U.S. Bureau of Land Management

This report is preliminary and has not been reviewed for conformity with

U.S. Geological Survey editorial standards and stratigraphic nomenclature. 


\section{STUDIES RELATED TO WILDERNESS \\ Bureau of Land Management Wilderness Study Area}

The Federal Land Policy and Management Act (Public Law 94-579, October 21, 1976) requires the U.S. Geological Survey and the U.S. Bureau of Mines to conduct mineral surveys on certain areas to determine the values, if any, that may be present. Results must be made available to the public and be submitted to the President and the Congress. This report presents the results of a mineral survey of the North Sisters Rocks Wilderness Study Area (OR-012-008), Curry County, Oregon. 


\section{CONTENTS}

Summary 1

Abstract 1

Character and setting 1

Identified resources 1

Mineral resource potential $\mathbf{3}$

Introduction 3

Location and physiography 3

Previous and present investigations 3

Appraisal of identified resources 5

History 5

Mineral deposits 6

Assessment of mineral resource potential 6

Geology 6

Geochemical studies 7

Mineral resource potential 8

References cited 9

Appendixes 11

Definition of levels of mineral resource potential and certainty of assessment $\mathbf{1 2}$

Resource/reserve classification 13

Geologic time chart 14

\section{FIGURES}

1. Index map showing location of the North Sisters Rocks Wilderness Study Area, Curry County, Oregon 2

2. Map showing simplified geology of the North Sisters Rocks Wilderness Study Area, Curry County, Oregon 4 


\section{SUMMARY}

\section{Abstract}

At the request of the U.S. Bureau of Land Management, the 3-acre North Sisters Rocks Wilderness Study Area (OR-012-008) was evaluated for mineral resources (known) and mineral resource potential (undiscovered). The U.S. Geological Survey and the U.S. Bureau of Mines examined the area and collected rock samples during the summer of 1986. The study area consists of three large rocks that are located along the Pacific coast in Curry County, southwest Oregon. No mines, prospects, or claims are situated in the study area, and no resources are identified. The most likely metals of interest to be found in the study area are chromium and nickel, however this study indicates that there is no potential for chromium and nickel resources in the study area.

\section{Character and Setting}

The North Sisters Rocks Wilderness Study Area (OR-012-008) is located along the south Oregon coast in Curry County, Oreg., about 15 mi south of Port Orford, Oreg. (fig. 1). The study area consists of the three largest of a cluster of rocks located about $0.5 \mathrm{mi}$ north of the rocky promontory known as Sisters Rocks. The surf-pounded rocks, or sea stacks, forming the study area are bounded by sheer wave-cut cliffs and are partly to completely isolated by ocean water from a sandy beach along the main shoreline. The geology of the study area is characterized by Jurassic and younger (see appendix for geologic time chart) tectonic-melange (a rock assemblage containing abundant exotic and native fault blocks chaotically arranged in a sheared matrix). The assemblage consists of variably sheared blocks of sedimentary and volcanic rocks and gabbro enclosed in a highly sheared serpentinite-bearing matrix. Local narrow, through-going shear zones containing sheared serpentinite cut the rocks along various trends. Veins composed primarily of pyrite-bearing calcite follow the shear zones whereas smaller, randomly oriented calcite veins are scattered throughout the rocks. Although much of the tectonism shown by the melange in the study area consisted of Jurassic and Cretaceous thrusting, later high-angle Tertiary faulting and shearing contributed significantly to the overall structural and lithologic complexity of the rocks. The lack of consistent structural trends throughout the study area suggests that the sea-stack blocks may not be firmly rooted in the bedrock, but rather may be displaced blocks associated with a large series of coastal landslide deposits located about $300 \mathrm{ft}$ east of the study area.

Quaternary marine-terrace deposits consisting of older beach sand and gravel cap the two largest seastacks in the study area.

There are no mines, prospects, or mining claims in the North Sisters Rocks Wilderness Study Area. An inactive gold beach-placer mine is $1 \mathrm{mi}$ north of the study area and three gold and chromite beach-placer prospects are within $3 \mathrm{mi}$ to the south. Two currently inactive stone quarries are located $0.5 \mathrm{mi}$ south and east of the study area.

\section{Identified Resources}

The North Sisters Rocks Wilderness Study Area has no identified resources. Stone from the study area does not constitute a construction-materials (including jetty stone) resource because of unfavorable physical characteristics and because nearby quarries have sufficient stone resources to satisfy local demand. 
Figure 1.--Index map showing location of the North Sisters Rocks Wilderness Study Area, Curry County, Oregon. 


\section{Mineral Resource Potential}

The North Sisters Rocks Wilderness Study Area has no positive indications of potential for mineral resource accumulations. Although somewhat anomalous concentrations of chromium and nickel were detected in local serpentinite-bearing shear zones, the geologic environment of the study area does not suggest that these metals occur in concentrated deposits. Anomalous chromium and nickel concentrations are not unusual in serpentinite and allied rocks. There is thus no potential for chromium and (or) nickel resources in the study area.

\section{INTRODUCTION}

This mineral survey was requested by the U.S. Bureau of Land Management (BLM) and is a joint effort by the U.S. Geological Survey (USGS) and the U.S. Bureau of Mines (USBM). An introduction to the wilderness review process, mineral survey methods, and agency responsibilities were provided by Beikman and others (1983). The USBM evaluates identified resources at individual mines and known mineralized areas by collecting data on current and past mining activities and through field examination of mines, prospects, claims, and mineralized areas. Identified resources are classified according to the system described by U.S. Bureau of Mines and U.S. Geological Survey (1980). Studies by the USGS are designed to provide a reasonable scientific basis for assessing the potential for undiscovered mineral resources by determining geologic units and structures, possible environments of mineral deposition, presence of geochemical and geophysical anomalies, and applicable ore-deposit models. Mineral assessment methodology and terminology as they apply to these surveys were discussed by Goudarzi (1984). See appendixes for the definition of levels of mineral resource potential, certainty of assessment, and classification of identified resources.

\section{Location and Physiography}

The North Sisters Rocks Wilderness Study Area (OR-012-008), encompassing about 3 acres, is located along the rugged southern coast of Oregon about $15 \mathrm{mi}$ south of Port Orford (fig. 1). The study area consists of three large wave-cut rocks, or sea stacks, that form part of a cluster of rocks distributed over about a $0.1 \mathrm{mi}^{2}$ area. The rocks comprising the study area are partly to completely separated by seawater from the main shoreline, depending on the tide level. The tops of the rocks are rounded and form gentle slopes in contrast to the subvertical-to-overhanging, surf-pounded cliffs forming their sides. A sandy beach abuts the study area on the landward side that is, in turn, bounded on the east by an extensive, moderately steep hummocky slope forming the main coastline.

Vegetation within the study area is limited to low shrubs and grasses that grow primarily on the soil-bearing tops of the rocks. Kelp and other types of marine plant life thriving along the bases of the rocks are intermittently exposed during low tide.

The study area is about $0.2 \mathrm{mi}$ west of U.S. Highway 101 (fig.1). The study area is most easily reached by driving $0.3 \mathrm{mi}$ west from Highway 101 on the Frankport quarry gravel road and then hiking about $0.5 \mathrm{mi}$ north along a sandy beach (fig. 2). Two of the study area rocks can be reached by foot except during high tide. Access to the third, or northernmost rock, is by boat, although this can be quite risky because of unpredictable currents and surf.

\section{Previous and Present Investigations}

Previous geologic mapping in the region included that of Diller (1903), Koch (1966), Hunter and others (1970), Dott (1971), Coleman (1972), and Beaulieu and 
Figure 2.--Map showing simplified geology of the North Sisters Rocks Wilderness Study Area, Curry County, Oregon. Geology modified from Koch (1966) and Hunter and others (1970). There is no potential for chromium or nickel resources, certainty level D, throughout the study area. 
Hughes (1976). The geology near the study area was described by these investigators and by Ramp and others (1977). Beaulieu and Hughes (1976) and Ramp and others (1977) also described the mineral resources and naturally occurring construction materials in the region.

The USGS conducted a geological reconnaissance of the study area in 1986 after doing a search of pertinent geologic literature. Ten rock-chip samples were collected from the principal rock units and possible mineralized areas for geochemical analysis and evaluation.

The USBM carried out a library search for information on mines and prospects in and adjacent to the study area. Published reports on mineral resources near the study area were supplemented by information from BLM mining claim recordation indices, county court house records, and USBM production records. Field studies were conducted in 1986, which included a search for mines, prospects, claims, or mineralized areas. One rock-chip and one beach-placer sample were collected from the study area by the USBM for analysis. Details of the sampling and analytical procedures and results of the USBM study are presented in Campbell (1987).

\section{APPRAISAL OF IDENTIFIED RESOURCES}

By Harry W. Campbell

U.S. Bureau of Mines

\section{History}

The first mining activity close to the study area was associated with the discovery of gold in black sand layers along the modern beach less than 0.5 mi south of the small town of Ophir (fig. 1). Placer mining was most active during the late 1850's and early 1860's. After the richest beach deposits were depleted, mining began in marine-terrace deposits located 1 to $5 \mathrm{mi}$ inland from the modern beaches. The richest and most profitable terrace deposits were worked during the early-to-middle 1870's (Hornor, 1918). Small-scale placer operations have continued on the beaches of southwestern Oregon since that time, especially after heavy storms have reconcentrated the black sands in favorable spots (Griggs, 1945). The Kalamazoo beach placer mine, located $1 \mathrm{mi}$ north of the study area (fig. 1), produced 399 ounces (oz) of gold from 1909 to 1912 using small-scale hand methods (Parks and Swartley, 1916; USBM production records). Placer gold prospects were also located 1.5 and $3 \mathrm{mi}$ south of the study area (fig. 1) (Ramp and others, 1977; Diller, 1903). Records of gold production from beach placers are incomplete, but $761 \mathrm{oz}$ of gold were reportedly produced from the Ophir-Gold Beach area from 1903 to 1929 (Pardee, 1934). During World War II the beaches of southern Oregon were extensively prospected for strategic minerals, resulting in the discovery of the Ophir chromite prospect about $2.5 \mathrm{mi}$ south of the study area (fig. 1). Black sand containing as much as 9.3 percent chromium oxide is concentrated at the prospect. (Griggs, 1945).

The privately owned Frankport quarry, located $0.5 \mathrm{mi}$ south of the study area at Sisters Rocks (fig. 2), has produced more than 150,000 cubic yards ( $\mathrm{yd}^{3}$ ) of stone for use as fill, road base, road metal, riprap, and jettystone (Ramp and others, 1977). The quarry is no longer considered a good site for obtaining jettystone because of the poor quality of the stone (U.S. Army Corps of Engineers, oral commun., 1986).

Another stone quarry located $0.5 \mathrm{mi}$ east of the study area (fig. 2) was operated by the Oregon State Highway division on state land. It produced less than $50,000 \mathrm{yd}^{3}$ of rock material for construction use. 


\title{
Mineral Deposits
}

There are no mines, prospects, or mining claims in the North Sisters Rocks Wilderness Study Area, and no mineral resources are identified. A chip sample of silicified igneous rock taken within the study area contains no metals or other elements approaching economic concentrations. A grab sample of beach sand taken at the base of the northern rock to help evaluate possible beach placers had a trace of black sand but no gold was observed.

Stone from the North Sisters Rocks Wilderness Study Area does not constitute a construction-materials resource because of the following factors: (1) the stone is nonuniform and has many of the unfavorable characteristics of stone from the Frankport quarry, such as shears and granulated zones; (2) the rocks are in an environmentally sensitive area (visible from U.S. Highway 101) along a scenic coast (U.S. Army Corps of Engineers, oral commun., 1986); and (3) the two nearby quarries (fig. 2) have sufficient stone resources to satisfy local demand for rock material (Campbell, 1987).

\section{ASSESSMENT OF MINERAL RESOURCE POTENTIAL}

\author{
By Scott A. Minor and Harley D. King \\ U.S. Geological Survey
}

\section{Geology}

The geology of southwest Oregon is structurally complex due to a long and varied tectonic history. Near the study area, several weakly metamorphosed Jurassic and Cretaceous sedimentary and volcanic rock formations and assemblages are juxtaposed and deformed by late Mesozoic low-angle thrust faults and Tertiary cross-cutting, high-angle strike-slip shear zones (Koch, 1966; Dott, 1971; Hunter and others, 1970). These "tectonostratigraphic terranes" consist of fault-bounded, stratigraphically cohesive assemblages that have been tectonically transported from various source terranes, some of them distant. Individual tectonostratigraphic terranes are mainly distinguished from one another by gross changes in stratigraphic assemblages. In southwest Oregon, the juxtaposition of several diverse tectonostratigraphic terranes and the accompanying deformation is attributed to complex plate-tectonic interactions along the west edge of the North American plate (see, for example, Blake and others, 1985).

Positive correlations of study area rocks with regionally mapped formations or assemblages are difficult because of the geologic complexity of the region, the small size of the study area, and the small scale (1:62,500 or smaller) of published geologic maps. Many of the rocks in the study area are tentatively correlated with the Jurassic Otter Point Formation (Blake and others, 1985), which underlies an extensive area directly south of the study area (fig. 2)(Koch, 1966; Dott, 1971). The Otter Point Formation, which comprises most of the Gold Beach tectonostratigraphic terrane of Blake and others (1985), consists of mudstone, sandstone, conglomerate, bedded chert, and basaltic volcanic rocks. Within the study area, however, mudstone was not observed in the Otter Point Formation. The sandstones and conglomerates present in the study area are lithic-rich and contain poorly sorted clasts in a silty matrix. The basaltic volcanic rocks, which show some signs of lowgrade metamorphism, are typically dark grey and aphanitic.

Highly sheared and brecciated gabbro makes up most of the remaining rocks in the study area. The gabbro is not considered to be part of the Otter Point Formation, although they are in tectonic juxtaposition. Cross-cutting shear zones with various orientations and thicknesses pervasively cut the gabbro. The shear zones contain granulated and sheared gabbro and are accompanied by sheared chlorite and serpentinite. Commonly, irregular- to lenticular-shaped blocks of rocks similar to those of the Otter Point Formation are in sheared contact with and enclosed by sheared gabbro, in typical melange fashion. On the 
southernmost rock in the study area, however, a large sheared homogeneous mass of gabbro is separated from rocks of the Otter Point Formation by a through-going, moderately low-angle, sharply defined (less than $0.5 \mathrm{~m}$ thick) shear zone (fig. 2). Koch (1966) mapped the rocks in the study area as the Pearse Peak (?) Diorite presumably on the basis of observations limited to the gabbro exposures. The Pearse Peak Diorite was originally named for rocks exposed northeast of the study area along the Elk River (fig. 1). If Koch's correlation is correct, the gabbro may have been transported tectonically to its present position from the Elk River area along thrust faults or other major shear zones.

Primary minerals and textures are difficult to identify in the gabbro because the rocks have undergone various degrees of metamorphism and alteration, depending mainly on the severity of deformation. Feldspar and pyroxenes make up the bulk of the rock. Metamorphic minerals include chlorite and possibly serpentine, which cause the gabbro to appear dark olive green in outcrop.

Calcite veins and secondary pyrite are present throughout the study area. The calcite veins generally are subparallel to nearby shear zones or occupy the zones. Fine- to coarse-grained pyrite aggregates usually accompany the calcite in shear zones and finegrained pyrite is also disseminated throughout most of the surrounding rocks. Quartz veins, although present, are much less numerous than the calcite veins. Small amounts of limonite were observed in one of the quartz veins.

The Port Orford shear zone, a wide north-northwest-trending major fault zone partly delineated by Koch (1966) and Hunter and others (1970), projects southward under the ocean at Port Orford and probably intersects the coast again at about the position of the study area (fig. 1). This shear zone separates rocks of the Otter Point Formation on the west from younger Lower Cretaceous sedimentary rocks on the east. The heterogeneous and highly sheared nature of the rocks in the study area may be an expression of the west edge of the Port Orford shear zone. However, the prominent local shear zones within the study area are not all parallel to the Port Orford trend and are inconsistent between individual sea stacks. One possible explanation of this variability is that the sea stacks have shifted independently of one another after the formation of the shears. An extensive landslide deposit is present directly east of the study area along the steep hummocky slope that descends from Highway 101 to the beach adjacent to the sea stacks (fig. 2). The sea stacks comprising the study area may thus be slide blocks that became disordered as they moved downslope with the landslide.

Thin (10 ft or less) veneers of marine-terrace sand and gravel rest on wave-cut platforms on the tops of the two largest rocks in the study area (fig. 2). These deposits are most likely Pleistocene in age and formed during an interglacial rise in sea level (for references, see Beaulieu and Hughes, 1976).

\section{Geochemical Studies}

Ten rock samples were collected from the study area during a reconnaissance geochemical study. Samples of unaltered rocks were collected and analyzed to obtain information on geochemical background values. Samples of altered and possibly mineralized rocks were collected to determine the geochemical signature of the observed alteration and mineralization. The rock samples were analyzed for 31 elements by semiquantitative emission spectroscopy (Grimes and Marranzino, 1968). Certain selected elements of special interest or elements that need to be detected at lower concentrations than the lower limits of determination by emission spectrography were also analyzed by other means. Gold and mercury were determined by atomic absorption and antimony, arsenic, bismuth, cadmium, and zinc by inductively coupled argon plasma-atomic emission spectroscopy, using methods described by Crock and others (1987). Anomalous values were determined by considering the range and distribution of the elemental concentrations as well as.published average crustal abundances of elements for the rock types. 
The only notably anomalous concentrations detected in the rock samples were those of chromium and nickel. Two samples yielded anomalous chromium values of 5,000 and greater than 5,000 parts per million (ppm) (M.S. Erickson, unpublished data, 1987). The sample with the $5,000 \mathrm{ppm}$ chromium value also contained an anomalous concentration of greater than 5,000 ppm nickel. Both of the samples were collected along prominent shear zones expressed by through-going calcite veins, sheared serpentinite, and pyrite aggregates. The chromium anomalies most likely reflect the presence of chromite, the principal chromium ore mineral. No chromite was identified with certainty in the study area, but this does not preclude the presence of finely disseminated, undetected grains. Chromite usually occurs as a primary accessory mineral in ultramafic and mafic plutonic rocks, and may also occur in serpentinite (Williams and others, 1982). The gabbro in the study area is one possible source of chromite, although the direct association of the high chromium values with the serpentine-bearing shear zones strongly suggests that most of the inferred chromite occurs in the serpentinite. The serpentinite and any accompanying chromite probably were derived from ultramafic rocks that were tectonically juxtaposed with the other rocks in the study area. In ultramafic rocks chromium has an average concentration of about $2,000 \mathrm{ppm}$ (Levinson, 1980), partially reflecting the presence of chromite. Presumably serpentinite, a metamorphosed ultramafic rock that usually contains remnent chromite, has a similar abundance of chromium. This abundance is of the same order of magnitude as the anomalous chromium concentrations detected in the study area and suggests that any chromite present does not occur in concentrated deposits.

The average abundance of nickel in ultramafic rocks is reported by Levinson (1980) as $2,000 \mathrm{ppm}$, which mainly reflects the presence of olivine, a principal constituent of ultramafic rocks. Upon serpentinization, or transformation to serpentinite, much of the nickel in ultramafic rocks goes into serpentine. The high nickel values are thus best explained as reflecting the presence of serpentine, which normally carries a relatively large amount of nickel.

\section{Mineral Resource Potential}

Reported regional mining and prospecting activity, geologic investigations, and geochemical anomalies do not provide any positive indication of potential for mineral resources in the North Sisters Rocks Wilderness Study Area.

Anomalous chromium concentrations are present in serpentinite samples collected along shear zones and probably reflect the presence of dispersed chromite grains, which commonly accompanies serpentinite. Primary chromite is a common accessory mineral in ultramafic rocks that usually survives later serpentinization, a metamorphic transformation of ultramafic rock to serpentine-rich rock under hydrous conditions (Williams and others, 1982). Chromite-bearing beach-sand placer deposits in the region, including the Ophir deposit 2.5 mi south of the study area (fig. 1), suggest that significant amounts of chromite are present in some of the rocks in the region. No chromite, however, was directly observed in the study area, and the geological and geochemical evidence indicate that any existing chromite does not occur in concentrated deposits. Thus there is no potential, with a certainty level of $\mathrm{D}$, for resource accumulations of chromium in the study area.

Like the high chromium values, anomalous concentrations of nickel are limited to shear zones partly occupied by serpentinite. The nickel anomalies are best explained as being expressions of serpentinized ultramafic rock occupying parts of the shear zones. Relatively large concentrations of nickel are commonly associated with such rocks, especially with the olivine component (Levinson, 1980). Nickel that is retained by serpentinite following serpentinization of ultramafic rock is highly dispersed. There is no potential, certainty level D, for accumulations of nickel large enough to be considered a resource in the study area. 


\section{REFERENCES CITED}

Beaulieu, J.D., and Hughes, P.W., 1976, Land use geology of western Curry County, Oregon: Oregon Department of Geology and Mineral Industries Bulletin 90, 148 p.

Beikman, H.M., Hinkle, M.E., Frieders, Twila, Marcus, S.M., and Edward, J.R., 1983, Mineral surveys by the Geological Survey and the Bureau of Mines of Bureau of Land Management Wilderness Study Areas: U.S. Geological Survey Circular 901, $28 \mathrm{p}$.

Blake, M.C., Jr., Engebretson, D.C., Jayko, A.S., and Jones, D.L., 1985, Tectonostratigraphic terranes in southwest Oregon, in Howell, D.G., ed., Tectonostratigraphic terranes of the circum-Pacific region, no. 1 of Circum-Pacific Council for Energy and Mineral Resources Earth Science Series: Houston, Texas, Circum-Pacific Council for Energy and Mineral Resources, p. 147-157.

Campbell, H.W., 1987, Mineral resources of the North Sisters Rocks Wilderness Study Area, Curry County, Oregon: U.S. Bureau of Mines Mineral Land Assessment Open-File Report MLA 29-87, 11 p.

Coleman, R.G., 1972, The Colebrooke Schist of southwestern Oregon and its relation to the tectonic evolution of the region: U.S. Geological Survey Bulletin 1339, 61 p.

Crock, J.G., Briggs, P.H., Jackson, L.L, and.Lichte, F.E., 1987, Analytical methods for the analysis of stream sediments and rocks from wilderness study areas: U.S. Geological Survey Open-File Report 87-84, 35 p.

Dott, R.H., Jr., 1971, Geology of the southwestern Oregon coast west of the 124th meridian: Oregon Department of Geology and Mineral Industries Bulletin 69, 63 p.

Diller, J.S., 1903, Description of the Port Orford quadrangle: U.S. Geological Survey Geologic Atlas of the United States Folio 89.

Goudarzi, G.H., 1984, Guide to preparation of mineral survey reports on public lands: U.S. Geological Survey Open-File Report 84-787, 51 p.

Griggs, A.B., 1945, Chromite-bearing sands of the southern part of the coast of Oregon: U.S. Geological Survey Bulletin 945-E, p. 113-150.

Grimes, D.J., and Marranzino, A.P., 1968, Direct-current arc and alternating-current spark emission spectrographic field methods for the semiquantitative analysis of geologic materials: U.S. Geological Survey Circular 591,6 p.

Hornor, R.R., 1918, Notes on the black sand deposits of southern Oregon and northern California: U.S. Bureau of Mines Technical Paper 196, 41 p.

Hunter, R.E., Clifton, H.E., and Phillips, R.L., 1970, Geology of the stacks and reefs off the southern Oregon coast: Oregon Department of Geology and Mineral Industries Ore Bin, v. 32, no. 10 , p. 185-201.

Koch, J.G., 1966, Late Mesozoic stratigraphy and tectonic history, Port Orford-Gold Beach area, southwestern Oregon coast: American Association of Petroleum Geologists Bulletin, v. 50, no. 1, p. 25-71. 
Levinson, A.A., 1980, Introduction to exploration geochemistry (2nd ed.): Wilmette, Illinois, Applied Publishing Limited, 924 p.

Pardee, J.T., 1934, Beach placers of the Oregon coast: U.S. Geological Survey Circular $8,41 \mathrm{p}$.

Parks, H.M., and Swartley, A.M., 1916, Mineral resources of Oregon: Oregon Bureau of Mines and Geology Handbook of the Mining Industry of Oregon, v. 2, no. 4, 306 p.

Ramp, Len, Schlicker, H.G., and Gray, J.J., 1977, Geology, mineral resources, and rock material of Curry county: Oregon Department of Geology and Mineral Industries Bulletin 93, 79 p.

U.S. Bureau of Mines and U.S. Geological Survey, 1980, Principles of a resource/reserve classification for minerals: U.S. Geological Survey Circular 831, 5 p.

Williams, Howel, Turner, F.J., and Gilbert, C.M.., 1982, Petrography: An introduction to the study of rocks in thin sections ( $2 \mathrm{~d}$ ed.): San Francisco, W.H. Freeman and Company, $626 \mathrm{p}$. 
APPENDIXES 


\section{DEFINITION OF LEVELS OF MINERAL RESOURCE POTENTIAL AND CERTAINTY OF ASSESSMENT}

LOW mineral resource potential is assigned to areas where geologic, geochemical, and geophysical characteristics define a geologic environment in which the existence of resources is permissive. This broad category embraces areas with dispersed but insignificantly mineralized rock as well as areas with few or no indications of having been mineralized.

MODERATE mineral resource potential is assigned to areas where geologic, geochemical, and geophysical characteristics indicate a geologic environment favorable for resource occurrence, where interpretations of data indicate reasonable likelihood of resource accumulation, and (or) where an application of mineral-deposit models indicates favorable ground for the specified type(s) of deposits.

HIGH mineral resource potential is assigned to areas where geologic, geochemical, and geophysical characteristics indicate a geologic environment favorable for resource occurence, where interpretations of data indicate a high degree of likelihood for resource accumulation, where data supports mineral-deposit models indicating presence of resources, and where evidence indicates that mineral concentration has taken place. Assignment of high resource potential to an area requires some positive knowledge that mineral-forming processes have been active in at least part of the area.

UNKNOWN mineral resource potential is assigned to areas where information is inadequate to assign low, moderate, or high levels of resource potential.

NO mineral resource potential is a category reserved for a specific type of resource in a well-defined area.

\section{Levels of Certainty}

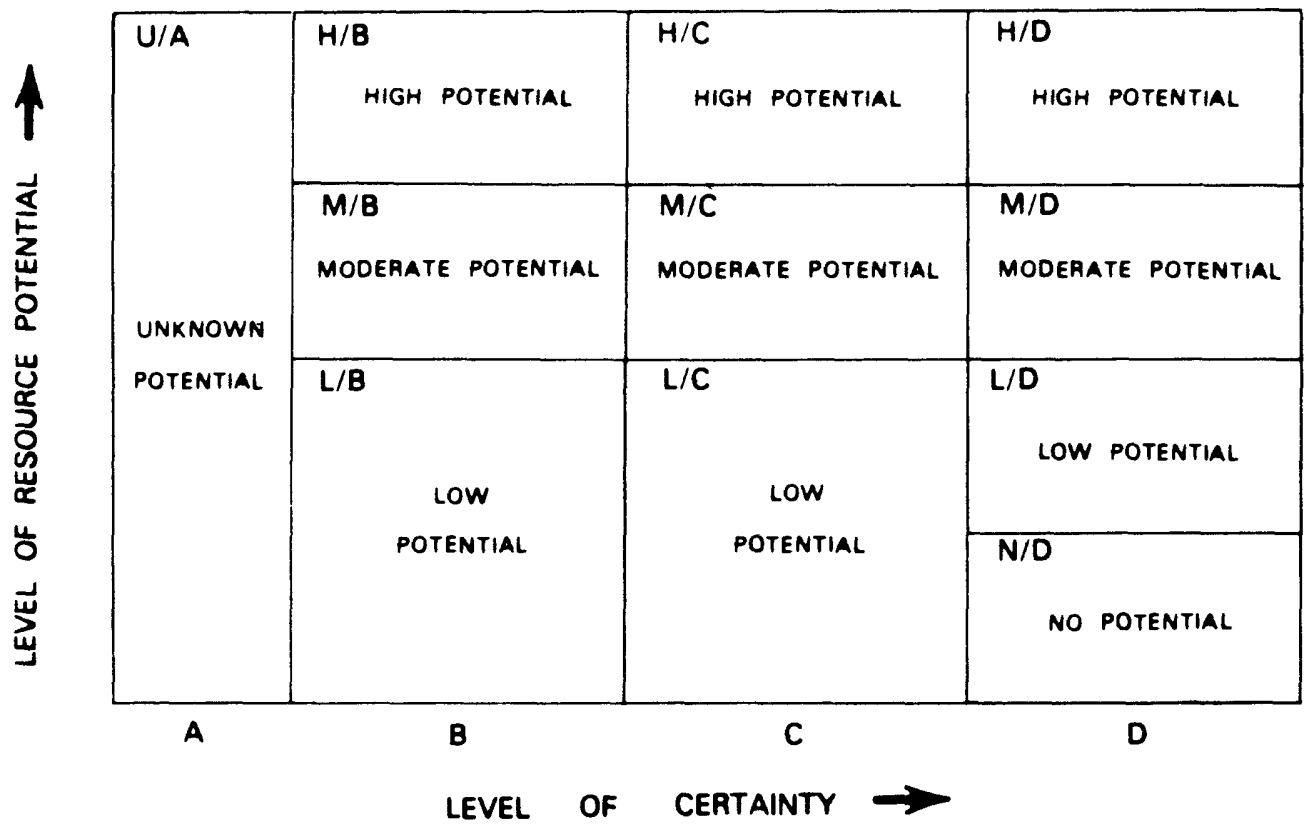

A. Available information is not adequate for determination of the level of mineral resource potential.

B. Available information suggests the level of mineral resource potential.

C. A vailable information gives a good indication of the level of mineral resource potential.

D. Available information clearly defines the level of mineral resource potential.

\section{Abstracted with minor modifications from:}

Taylor, R. B., and Steven, T. A., 1983, Definition of mineral resource potential: Economic Geology, v. 78, no. 6, p. $1268-1270$.

Taylor, R. B., Stoneman, R. J., and Marsh, S. P., 1984, An assessment of the mineral resource potential of the San Isabel National Forest, south-central Colorado: U.S. Geological Survey Bulletin 1638, p.
$40-42$.

Goudarzi, G. H., compiler, 1984, Guide to preparation of mineral survey reports on public lands: U.S. Geological Survey Open-File Report 84-0787, p. 7, 8. 


\section{RESOURCE/RESERVE CLASSIFICATION}

\begin{tabular}{|c|c|c|c|c|c|}
\hline & \multicolumn{3}{|c|}{ IDENTIFIED RESOURCES } & \multirow{2}{*}{\multicolumn{2}{|c|}{$\begin{array}{c}\text { UNDISCOVERED RESOURCES } \\
\text { Probability Range }\end{array}$}} \\
\hline & \multicolumn{2}{|c|}{ Demonstrated } & \multirow[t]{2}{*}{ Inferred } & & \\
\hline & Measured & Indicated & & Hypothetical & Speculative \\
\hline ECONOMIC & & & $\begin{array}{l}\text { Inferred } \\
\text { Reserves }\end{array}$ & & \\
\hline $\begin{array}{l}\text { MARGINALLY } \\
\text { ECONOMIC }\end{array}$ & $\begin{array}{l}\mathrm{Me} \\
\mathrm{Re}\end{array}$ & & $\begin{array}{l}\text { Inferred } \\
\text { Marginal } \\
\text { Reserves }\end{array}$ & & \\
\hline $\begin{array}{c}\text { SUB- } \\
\text { ECONOMIC }\end{array}$ & $\begin{array}{r}\text { Deme } \\
\text { Sube } \\
\text { Res } \\
\end{array}$ & $\begin{array}{l}\text { rated } \\
\text { omic } \\
\text { ces }\end{array}$ & $\begin{array}{l}\text { Inferred } \\
\text { Subeconomic } \\
\text { Resources }\end{array}$ & & \\
\hline
\end{tabular}

Major elements of mineral resource classification, excluding reserve base and inferred reserve base. Modified from U.S. Bureau of Mines and U.S. Geological Survey, 1980, Principles of a resource/reserve classification for minerals: U.S. Geological Survey Circular 831, p. 5. 
GEOLOGIC TIME CHART

Terms and boundary ages used by the U.S. Geological Survey in this report

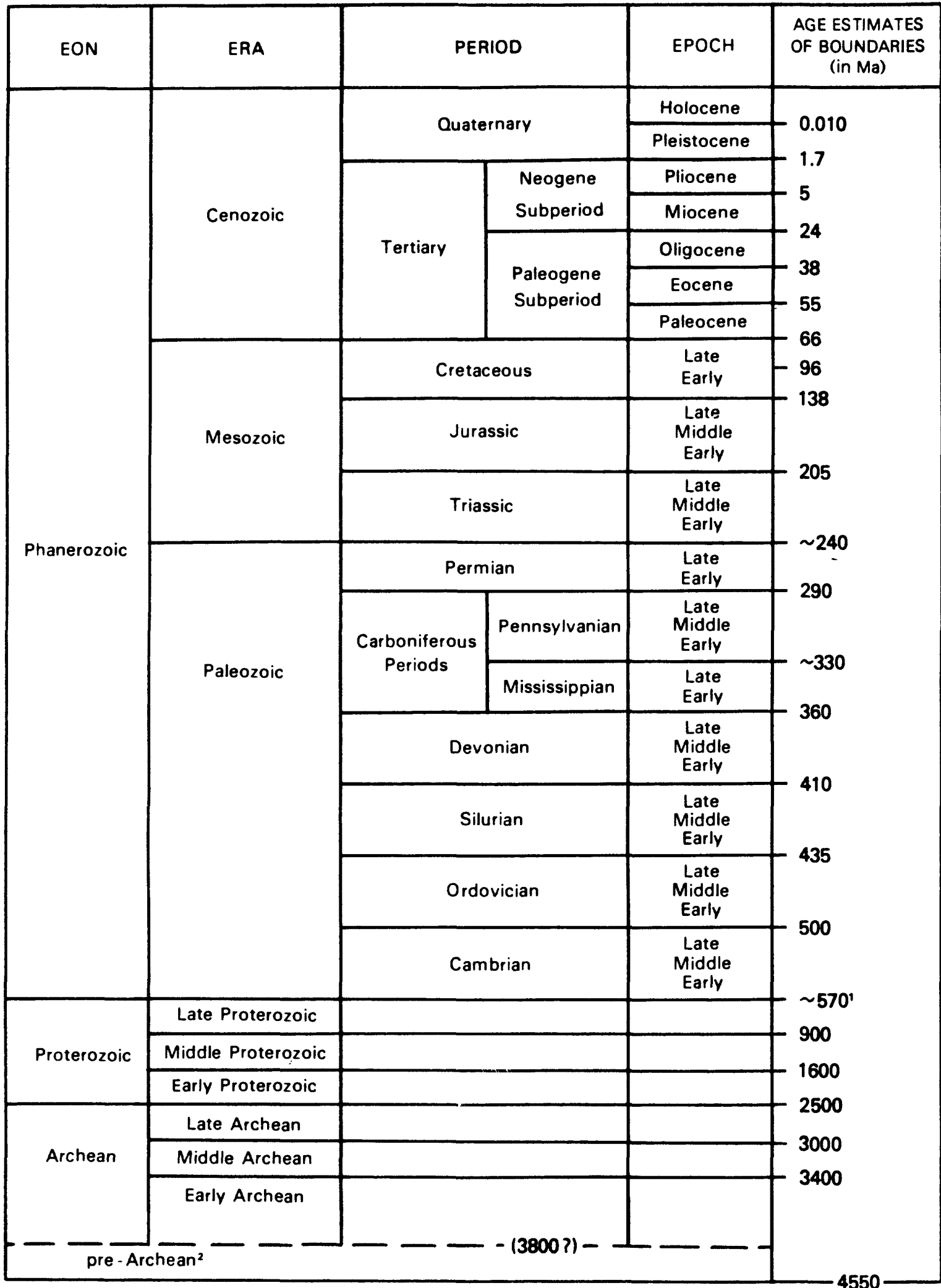

'Rocks older than $570 \mathrm{Ma}$ also called Precambrian, a time term without specific rank.

Informal time term without specific rank. 